\title{
Bioprospecção de biossurfactantes em candida infanticola ufsj6A E UFSJ7A
}

Cibele G. Bastos*, Danielle de Almeida, Fernanda S. Carvalho, Adriano G. Parreira, Daniel B. Gonçalves, José A. da Silva, Paulo A. Granjeiro

Curso de Bioquímica, Universidade Federal de São João Del-Rei, Divinópolis/MG

*e-mail: cibelegarciab@hotmail.com

\section{Resumo}

Biossurfactantes (BS) são compostos produzidos por bactérias, fungos ou leveduras, capazes de reduzir a tensão superficial da água, característica de grande interesse industrial, além de serem considerados não tóxicos e biodegradáveis. Apresentam aplicações potenciais em diversas áreas industriais, como no setor farmacêutico, de cosméticos, petróleo, alimentícios e médico. São moléculas anfipáticas classificadas de acordo com sua estrutura, como glicolipídeos e lipopeptídeos. Os principais microrganismos produtores de biossurfactante são Pseudomonas sp., Bacillus sp. e Candida sp. O objetivo desse trabalho foi realizar a bioprospecção de biossurfactantes a partir da levedura Candida infanticola UFSJ6A e UFSJ7A, isolada de efluente têxtil e a caracterização por teste do colapso da gota e avaliação da tensão superficial. A produção foi efetuada em meio adequado para seu crescimento utilizando óleo de soja como única fonte de carbono, durante 168 horas em um shaker a $28^{\circ} \mathrm{C}$. Em seguida, foi realizado o método de extração com solventes orgânicos clorofórmio:metanol:butanol (1:1:1). Este procedimento foi efetuado em ambas as linhagens de $C$. infanticola e assim realizando o teste de colapso da gota, onde se comparou com a água, observou-se que apenas o produto obtido da $C$. infanticola UFSJ7A espalhou-se, indicando a presença de uma substância tensoativa, sendo necessário medir a tensão das amostras. O produto obtido da C. infanticola UFSJ6A e 7A reduziram a tensão de $72 \mathrm{mN} / \mathrm{m}$ (tensão superficial da água) para $35 \mathrm{mN} / \mathrm{m}$ em uma concentração de $20 \mathrm{mg} / \mathrm{mL}$ e $5 \mathrm{mg} / \mathrm{L}$, respectivamente. Concluímos que o método de extração foi eficiente para isolar o BS e a redução de tensão superficial do BS foi um avanço para a descoberta de um microrganismo produtor de BS, porém são necessários novos ensaios para a 
completa caracterização estrutura e abrir perspectivas para sua aplicação em vários setores produtivos.

Palavras-chaves: biossurfactante, candida infanticola, tensão superficial Apoio financeiro: $\mathrm{CNPq}$, FAPEMIG 